\title{
Urine patch size and nitrogen load: effects on nitrogen uptake from the urine patch in plantain and ryegrass/white clover pastures
}

\author{
M.A. SHEPHERD and W.T. CARLSON \\ AgResearch Ruakura, Private Bag 3123, Hamilton 3240, New Zealand \\ mark.shepherd@agresearch.co.nz
}

\begin{abstract}
Field measurements from micro-plots $\left(0.20-0.36 \mathrm{~m}^{2}\right)$ of perennial ryegrass/white clover and of pure plantain were used to mimic a urine patch (UP) and to test the effects of UP nitrogen $(\mathrm{N})$ load and size on pasture N offtake. Urine $\mathrm{N}$ offtake was greater with plantain than with standard pasture; however, the relative contribution to uptake from the wetted area and surrounding edge was the same for both species. Most $(>90 \%)$ of the apparent offtake of urine $\mathrm{N}$ by plantain and standard pastures was within $20 \mathrm{~cm}$ of the edge of the UP. For the two urine patch sizes tested, edge contribution to urine $\mathrm{N}$ offtake was on average about $30 \%$ of the total from the UP, but was higher for at $600 \mathrm{~kg} \mathrm{~N} /$ ha urine $\mathrm{N}$ $(45 \%)$ than at $300 \mathrm{~kg} \mathrm{~N} / \mathrm{ha}(18 \%)$. Understanding this edge contribution is important for model improvement, and for the development of mitigations to decrease $\mathrm{N}$ leaching.
\end{abstract}

Keywords: urine patch edge, wetted area, nitrogen dynamics, leaching

\section{Introduction}

The urine patch (UP) area can be divided into a wetted area (where urine was directly voided) and the immediate surrounding area. Pasture plants outside of the wetted area can access urinary $\mathrm{N}$ via their roots and nitrogen $(\mathrm{N})$ diffusion/convection through the soil (Lantinga et al. 1987; Tinker \& Nye 2000; Cichota et al. 2018). An understanding of pasture growth and $\mathrm{N}$ uptake through this 'edge contribution' is important (Moir et al. 2011). Firstly, lysimeters used for measuring $\mathrm{N}$ leaching losses have confined edges, but the contribution to uptake of urinary $\mathrm{N}$ by pasture over the entire effective area should be considered because $\mathrm{N}$ leaching is generally inversely related to $\mathrm{N}$ uptake (Moir et al. 2013). Secondly, some mitigation options under development look to alter the size and shape of UPs and this can change the contribution of the UP edge to uptake (Balvert \& Shepherd 2015). Furthermore, research has focused on standard perennial ryegrass (Lolium perenne) and white clover (Trifolium repens) pastures, whereas there is currently interest in alternative pasture species as forage.

The aim of this paper is to report some data from a larger study that compared offtake from wetted and
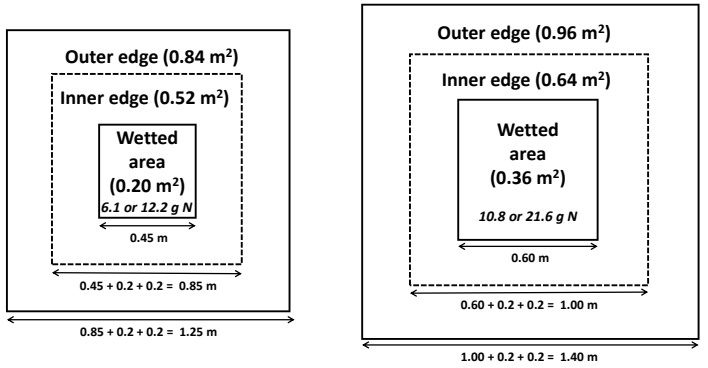

Figure 1 The two micro-plot sizes, showing zones and the relative area of each separate zone. Numbers in italics are the amounts of urine $\mathrm{N}(\mathrm{g})$ applied to the wetted area equivalent to application rates of 300 and $600 \mathrm{~kg} \mathrm{~N} / \mathrm{ha}$.

edge areas of pasture micro-plots mimicking UPs. The hypotheses were that the edge component of the UP makes a substantial contribution to overall $\mathrm{N}$ offtake and that plantain (Plantago lanceolata) and standard pastures, would perform similarly in terms of edge effects. Understanding this edge contribution is important for model improvement, and for the development of mitigations to decrease $\mathrm{N}$ leaching.

\section{Approach}

A replicated experiment was established at Scott Farm, Hamilton, New Zealand, in the spring of 2015 to compare growth and $\mathrm{N}$ offtake from micro-plots of pure plantain and standard perennial ryegrass/white clover pastures (clover about 15\% of DM) representing urine patches to (a) determine the relative contribution of wetted area and outside area to $\mathrm{N}$ removal from the urine patch and (b) to test if these differed between the pasture species. The overall design of the experiment was based on previous experiments with ryegrass/white clover pastures (Balvert \& Shepherd 2015; Buckthought et al. 2016); the novelty in this experiment was the comparison of species. Square micro-plots, were used to mimic urine patches and to make harvesting easier. Each comprised a 'wetted area' and two concentric zones $20 \mathrm{~cm}$ wide denoted as the 'inner' and 'outer' edge (Figure 1). Adjacent Nil-N strips $\left(2 \mathrm{~m}^{2}\right)$ acted as control areas.

Two square UP areas $\left(0.20\right.$ and $0.36 \mathrm{~m}^{2}$ typical of the range of cattle urine patches were compared, Selbie et al. 2015) and two urinary $\mathrm{N}$ rates (300 and 600 
$\mathrm{kg} \mathrm{N} /$ ha equivalent) in three paddock replicates on a Horotiu silt loam soil. Artificial urine was applied in a single application to UPs at a rate of $10 \mathrm{~L} / \mathrm{m}^{2}$, with $\mathrm{N}$ concentration of the urine adjusted to achieve the desired loadings of either 300 or $600 \mathrm{~kg} \mathrm{~N} / \mathrm{ha}$, i.e. 3 or $6 \mathrm{~g} \mathrm{~N} / \mathrm{L}$. Urine analysis for total $\mathrm{N}$ concentration before use confirmed that the target concentrations were achieved. Urine treatments were applied after the forage had been mown to simulate a residual height of about $5 \mathrm{~cm}$. Applications dates were 9th September (plantain) and 16th September (standard), with final harvests on 15th January (plantain, five harvests, 128 days in total) and 19th January (standard, four harvests, 124 days in total). Application dates differed by a week to synchronise with separate experimental work on the same site. Number of harvests differed between species because of differential growth rates.

Pasture was harvested by mower to determine pasture response and by harvesting the 'zones' of the plot separately (wetted area and the edges). Control strips $\left(1.8 \mathrm{~m}^{2}\right)$ were also harvested from where no treatment or $\mathrm{N}$ fertiliser had been applied. Herbage samples were taken from each plot to determine dry matter (DM\%) and nitrogen contents (N\%). Sample DM\% was determined by drying a subsample at $65^{\circ} \mathrm{C}$ for 48 hours; $\mathrm{N}$ content was determined by Kjeldahl analysis.

\section{Expression of results}

The combination of UP size and N load/UP meant that the four UPs received different amounts of N (Figure 1). This and the differences in areas of each zone as affected by UP size (Figure 1) needed to be factored into calculations of relative $\mathrm{N}$ offtake from each zone; expression of results on a ha basis was meaningless for this comparison, given the difference in the area of each zone.

The following calculation procedure was therefore followed:

1. Calculate net ('apparent') $\mathrm{N}$ offtake (kg N/ha) from zones by subtracting control $\mathrm{N}$ offtake:

Net Noff $(\mathrm{kg} \mathrm{N} / \mathrm{ha})_{\text {zone }}=\operatorname{Noff}(\mathrm{kg} \mathrm{N} / \mathrm{ha})_{\text {zone }}-$ Noff ( $\mathrm{kg} \mathrm{N} / \mathrm{ha})_{\text {control }}$

2. Calculate apparent $\mathrm{N}$ offtake $(\mathrm{g} \mathrm{N})$ from each zone:

$\operatorname{Net} \operatorname{Noff}(\mathrm{g} \mathrm{N})_{\text {zone }}=\mathrm{N}$ off $(\mathrm{kg} \mathrm{N} / \mathrm{ha})_{\text {zone }} \mathrm{x}$ Area ${ }_{\text {zone }}$

Table 1 Monthly rainfall and average air temperature, compared with the long-term average (LTA) from September 2015 to February 2016. Data: NIWA Virtual Climate Station.

\begin{tabular}{lcccccc}
\hline & Sep & Oct & Nov & Dec & Jan & Feb \\
\hline Rain $(\mathrm{mm})$ & 119 & 36 & 106 & 25 & 82 & 68 \\
LTA & 101 & 91 & 58 & 91 & 82 & 43 \\
\hline Temperature $\left({ }^{\circ} \mathrm{C}\right)$ & 11.6 & 13.7 & 15.1 & 17.3 & 20 & 21.5 \\
LTA & 11.9 & 13.2 & 14.9 & 17.2 & 18.9 & 19.4 \\
\hline
\end{tabular}

3. Calculate total apparent $\mathrm{N}$ offtake from a UP by summing zones:

Total Net Noff $(\mathrm{g} \mathrm{N})=\operatorname{Noff}(\mathrm{g} \mathrm{N})_{\text {wetted zone }}+\operatorname{Noff}(\mathrm{g}$ $\mathrm{N})_{\text {inner zone }}+$ Noff $(\mathrm{g} \mathrm{N})$ outer zone

4. Express total apparent $\mathrm{N}$ offtake as a proportion of urine $\mathrm{N}$ applied:

Net Noff $(\%$ applied $)=$ Net Noff $(g$ N $) \times 100 /$ N applied ( $\mathrm{g} \mathrm{N})$

\section{Statistical analysis}

Analysis of variance was performed on all the data using the GenStat statistical program (13th Edition). The Least Significant Difference (LSD) was calculated at $\mathrm{P}<0.05$.

\section{Results \\ Climate}

Air temperatures from September - December 2015 were close to the long-term average, but January and February were about two degrees warmer than average (Table 1). Rainfall from July-September 2015 was near normal, and soil conditions were moist at the time of the treatment applications to the plantain and standard pastures. Heavy rain $(16 \mathrm{~mm})$ fell in the night after the plantain treatment application. October was drier than average. Higher than average rainfall provided for uninhibited pasture growth in November, while December was dry followed by average rainfall in January.

\section{Pasture production and nitrogen offtake - wetted area}

There was no additional observable response by the pastures to the applied $\mathrm{N}$ beyond the first three harvests (data not shown). Over the total measurement period, more pasture DM was produced and more $\mathrm{N}$ taken up after urine application for plantain than for standard pasture (Table 2). There was also an effect of $\mathrm{N}$ rate, but not for urine patch size on pasture production and $\mathrm{N}$ offtake.

\section{Contribution of edge areas to $\mathrm{N}$ offtake}

Total apparent $\mathrm{N}$ offtake of urine $\mathrm{N}$ (as a total of the three zones, i.e. the 'effective area') was greater for plantain than for standard, and greater for $600 \mathrm{~N}$ than $300 \mathrm{~N}$ (Table 3). Average apparent $\mathrm{N}$ recovery (as a total of the effective area) was $45 \%$, i.e. about half of the applied $\mathrm{N}$ was recovered by the pasture. However, the apparent $\mathrm{N}$ recovery was greater for plantain than for standard 
pasture (67 versus $25 \%$; $\mathrm{P}<0.01$ ); there were no urine patch size or $\mathrm{N}$ load effects on the $\mathrm{N}$ recovery.

In terms of the contribution to apparent $\mathrm{N}$ offtake by each zone, there were differences in absolute amounts of $\mathrm{N}$ taken up by the two pastures, but there was no difference between species in the relative contribution of each zone. More than $90 \%$ of total apparent N offtake occurred in the wetted zone and within $20 \mathrm{~cm}$ of the wetted zone for both pastures (Table 4). However, there was an indication that the edge contribution became more important at the higher $\mathrm{N}$ rate (Table 4$)$.

\section{Discussion}

The average $\mathrm{N}$ recovery of $25 \%$ is low for a ryegrass/ white clover pasture. For example, Moir et al. (2013) measured on average 30 and $50 \%$ recovery in harvested DM from 13 grass species at $\mathrm{N}$ rates of 750 and 300 $\mathrm{kg} \mathrm{N} / \mathrm{ha}$ (mean 40\%), respectively. Nil $\mathrm{N}$ yield of the standard pasture was about $90 \%$ of the plantain, but only around $70 \%$ of plantain when urine was applied (Table 2). The low growth and low recoveries by the standard pasture were consistent across the three separate paddocks and are difficult to explain. The extra $16 \mathrm{~mm}$ rain after urine application to plantain was the only important difference in growing conditions, but it is difficult to see why this would have such a large effect. Critically, however, the proportions in each zone were similar between the two pasture types despite the differences in absolute amounts of $\mathrm{N}$ taken up.

Moir et al. (2011) noted a seasonal pattern in UP size (smaller in winter than in spring), and also noted that research is required to establish a

$\mathrm{NS}=$ Not significant. rate. clear relationship between the area wetted by urine and the associated pasture growth response (and hence, $\mathrm{N}$ offtake). Limited research suggests that extra $\mathrm{N}$ uptake from the wetted area is mainly restricted to pasture in the zone 150-200 $\mathrm{mm}$ from the edge (e.g. Deenan \& Middelkoop 1992; Decau et al. 2003). Data from this experiment support this finding, although there was an indication at high urinary $\mathrm{N}$ rates, of pasture access or diffusion/convection of $\mathrm{N}$ resulting in some uptake

Table 2 Total dry matter (DM) production and nitrogen (N) offtake from the wetted urine patch area for plantain and standard pastures (mean of both urine patch sizes).

\begin{tabular}{|c|c|c|c|c|}
\hline & \multirow{2}{*}{$\begin{array}{l}\text { Urine } N \text { rate } \\
\text { (kg N/ha) }\end{array}$} & \multicolumn{3}{|c|}{ Pasture species } \\
\hline & & Plantain & Standard & Mean \\
\hline \multirow[t]{4}{*}{ DM production (t/ha) } & 300 & 8.20 & 6.62 & 7.41 \\
\hline & 600 & 10.69 & 7.11 & 8.90 \\
\hline & Mean & 9.44 & 6.87 & \multirow{2}{*}{$\begin{array}{c}\mathrm{LSD}_{5 \%}=1.41 \\
\mathrm{P}<0.05\end{array}$} \\
\hline & & \multicolumn{2}{|c|}{$\mathrm{LSD}_{5 \%}=1.99, \mathrm{P}<0.05$} & \\
\hline \multirow[t]{4}{*}{ N offtake (kg/ha) } & 300 & 202 & 160 & 181 \\
\hline & 600 & 300 & 190 & 245 \\
\hline & Mean & 251 & 175 & \multirow{2}{*}{$\begin{array}{c}\mathrm{LSD}_{5 \%}=37 \\
\mathrm{P}<0.01\end{array}$} \\
\hline & & \multicolumn{2}{|c|}{$\mathrm{LSD}_{5 \%}=53, \mathrm{P}<0.01$} & \\
\hline
\end{tabular}

Associated nil-N yields were $4808 \pm \mathbf{4 8 4}$ (plantain) and $\mathbf{4 3 2 1} \pm \mathbf{6 8 4}$ (standard) $\mathrm{kg} \mathrm{DM/ha}$, and Nil-N N offtakes were $117 \pm 21.5$ (plantain) and $117 \pm 27.9$ (standard) $\mathrm{kg} \mathrm{N} / \mathrm{ha}$.

Table 3 Apparent $\mathrm{N}$ offtake and $\mathrm{N}$ recovery (as a total of the three urine patch zones) for plantain and standard pastures.

\begin{tabular}{|c|c|c|c|c|}
\hline & $\begin{array}{l}\text { Urine N rate } \\
\text { (kg N/ha) }\end{array}$ & Plantain & $\begin{array}{l}\text { Sture speci } \\
\text { Standard }\end{array}$ & Mean \\
\hline Apparent $\mathrm{N}$ offtake & 300 & 6.6 & 0.5 & 7.9 \\
\hline \multirow[t]{3}{*}{$(\mathrm{g} \mathrm{N})$} & 600 & 10.2 & 5.6 & 3.6 \\
\hline & Mean & 8.4 & 3.1 & \multirow{2}{*}{$\begin{array}{c}\mathrm{LSD}_{5 \%}=3.2 \\
\mathrm{P}<0.01\end{array}$} \\
\hline & & \multicolumn{2}{|c|}{$\mathrm{LSD}_{5 \%}=4.6, \mathrm{P}<0.05$} & \\
\hline Apparent $\mathrm{N}$ recovery & 300 & 67.0 & 15.1 & 41.1 \\
\hline \multirow[t]{3}{*}{ (\% of applied) } & 600 & 66.7 & 34.6 & 50.7 \\
\hline & Mean & 66.9 & 24.9 & \multirow{2}{*}{$\begin{array}{c}\mathrm{LSD}_{5 \%}=25.9 \\
\text { NS }\end{array}$} \\
\hline & & \multicolumn{2}{|c|}{$\mathrm{LSD}_{5 \%}=36.7, \mathrm{P}<0.05$} & \\
\hline
\end{tabular}

Table 4 The proportion of total apparent $\mathrm{N}$ offtake in each zone, as affected by $\mathrm{N}$ application

\begin{tabular}{|c|c|c|c|}
\hline & \multicolumn{3}{|c|}{ Urine $\mathrm{N}$ rate (kg N/ha) } \\
\hline & 300 & 600 & Mean \\
\hline Patch & 82 & 55 & 69 \\
\hline Inner edge & 16 & 35 & 25 \\
\hline \multirow[t]{2}{*}{ Outer edge } & 2 & 10 & 6 \\
\hline & \multicolumn{2}{|c|}{$\mathrm{LSD}_{5 \%}=18.0, \mathrm{P}<0.01$} & $\mathrm{LSD}_{5 \%}=12.7, \mathrm{P}<0.001$ \\
\hline
\end{tabular}




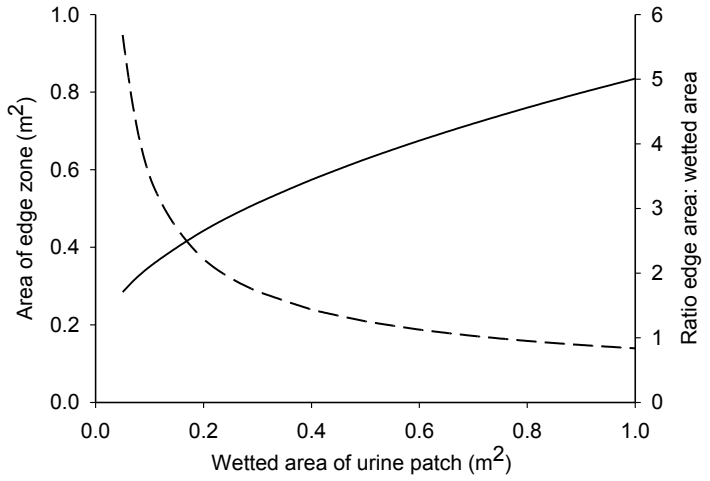

Figure 2 The effect of urine patch size (assumed to be circular) on the area of the edge zone (calculated assuming the width of edge zone was $20 \mathrm{~cm}$, solid line) and the edge zone area relative to the wetted area (broken line).

beyond $20 \mathrm{~cm}$. Table 4 shows that, as an average of the two $\mathrm{N}$ rates, an amount of $\mathrm{N}$ equivalent to $44 \%$ of the wetted area offtake occurred outside the wetted area (31 as proportion of $69=45 \%$ ). Phillips \& Shepherd (2013) estimated that $\mathrm{N}$ offtake outside of the UP was equivalent to around $50 \%$ of the offtake within the wetted area. Buckthought et al. (2016), using ${ }^{15} \mathrm{~N}$ labelled urine, reported similar results. The implications are that surplus $\mathrm{N}$ within a UP is depleted more rapidly if pasture outside of the wetted area is able to access urinary N. Accounting for this in models is important to correctly estimate $\mathrm{N}$ losses (leaching and gaseous) from urine patches, paddocks and farms, since urine patches are the major source of $\mathrm{N}$ loss. The lateral spread of urinary $\mathrm{N}$ beyond the patch area can reduce the effective $\mathrm{N}$ load of urine patches, enabling more plants to access the deposited $\mathrm{N}$ and consequently reduce $\mathrm{N}$ leaching losses; in the case of modelling of $\mathrm{N}$ leaching from a UP $60 \mathrm{~cm}$ in diameter (Cichota et al. 2018 ), this decreased by $8-37 \%$ when edge contribution to uptake was included in the model.

The $20 \mathrm{~cm}$ band around a urine patch represents an important additional area of pasture for $\mathrm{N}$ removal from the UP (Figure 2). However, more striking than the changes in absolute area with change in UP size, was the change in relative area between wetted and edge areas as the UP size decreased. Figure 2 shows the change in relative areas was small for the UP sizes that were tested ( 2.2 for a UP size $0.2 \mathrm{~m}^{2}$ and 1.5 for a UP $0.36 \mathrm{~m}^{2}$ ). This small difference in relative edge areas between the two UP sizes is perhaps why there was no statistically significant size effect on the relative edge contribution to urine $\mathrm{N}$ recovery. Figure 2 sets up the hypothesis that UPs have to be $<0.2 \mathrm{~m}^{2}$ for the edge effect to substantially increase relative to the wetted area, although this calculation can provide only a possible approximation of the response, it suggests a hypothesis for further evaluation. The challenge is that testing this by field experimentation is fraught with difficulty given the practical aspects of accurate measurement at this plot scale. The use of process-based models of urine patch dynamics such as that reported by Cichota et al. (2018), allows a much wider range of scenarios to be evaluated in terms of UP size, shape and $\mathrm{N}$ load than can be undertaken in field experiments, provided that the model is adequately verified against field data.

\section{ACKNOWLEDGEMENTS}

This research was funded by AgResearch SSIF as a contribution to the Forages for Reduced Nitrate Leaching (FRNL) research programme. FRNL has principal funding from the New Zealand Ministry of Business, Innovation and Employment (DNZ1301) and is a partnership between DairyNZ, AgResearch, Plant \& Food Research, Lincoln University, and the Foundation for Arable Research and Landcare Research.

\section{REFERENCES}

Balvert, S.; Shepherd, M. 2015. Does size matter? The effect of urine patch size on pasture $\mathrm{N}$ uptake. pp. 1-4. In: Moving farm systems to improved attenuation. Eds. Currie, L.D.; Burkitt, L.L. Occasional Report No. 28. Fertilizer and Lime Research Centre, Massey University, Palmerston North, New Zealand.

Buckthought, L.E.; Clough, T.J.; Cameron, K.C.; Di, H.J.; Shepherd, M.A. 2016. Plant N uptake in the periphery of a bovine urine patch: determining the 'effective area'. New Zealand Journal of Agricultural Research 59: 122-140.

Cichota, R.; Vogeler, I.; Snow, V.; Shepherd, M.; McAuliffe, R.; Welten, B. 2018. Lateral spread affects nitrogen leaching from urine patches. Science of the Total Environment 635: 1392-1404.

Decau, M.L.; Simon, J.C.; Jacquet, A. 2003. Fate of urine nitrogen in three soils throughout a grazing season. Journal of Environmental Quality 32: 1405-1413.

Deenen, P.; Middelkoop, N. 1992. Effects of cattle dung and urine on nitrogen uptake and yield of perennial ryegrass. Netherlands Journal of Agricultural Science 40: 469-482.

Lantinga, E.; Keuning, J.; Groenwold, J.; Deenen, P. 1987. Distribution of excreted nitrogen by grazing cattle and its effects on sward quality, herbage production and utilization. pp. 103-117. In: Animal manure on grassland and fodder crops. Fertilizer or waste? Vol. 30 of the series Developments in Plant and Soil Sciences. Springer, Dordrecht.

Moir, J.L.; Cameron, K.C.; Di, H.J.; Fertsak, U. 2011. The spatial coverage of dairy cattle urine patches in an intensively grazed pasture system. Journal of Agricultural Science 149: 473-485. 
Moir, J.L.; Edwards, G.R.; Berry, L.N. 2013. Nitrogen uptake and leaching loss of thirteen temperate grass species under high N loading. Grass and Forage Science 68: 313-325.

Phillips, P.; Shepherd, M. 2013. The effect of time of urine application on nitrate-nitrogen leaching risk. AgResearch report RE500/2013/10.
Selbie, D.R.; Buckthought, L.E.; Shepherd, M.A. 2015. The challenge of the urine patch for managing nitrogen in grazed pasture systems. Advances in Agronomy 129: 229-292.

Tinker, P.B.; Nye, P.H. 2000. Solute movement in the rhizosphere, Oxford University Press, U.K. p.444. 
